http://dx.doi.org/10.4314/jae.v16i1.5

\title{
Adaptation Practices to Climate Change Among Rice Farmers in Anambra State of Nigeria
}

\author{
H. U. Nwalieji* and E. A. Onwubuya** \\ Phone Number: $07033994751^{*}$ and $08050338606^{\star \star}$ \\ Addresses: Department of Agricultural Economics and Extension, Anambra State \\ University, Igbariam campus. * \\ Department of Agricultural Extension, University of Nigeria Nsukka.* \\ E-mail Addresses: nwaliejihyacinth@yahoo.com* and lizzybuya@yahoo.com**
}

\begin{abstract}
The study examined adaptation practices to climate change among rice farmers in Anambra State, Nigeria. Data were collected from 100 rice farmers by the combination of multistage, purposive and simple random sampling techniques, through the use of interview schedule. Percentage and mean statistics were used for data analysis. The results showed that majority $(80.0 \%)$ of the respondents were aware of climate change and its adaptation measures in rice production included the use of improved varieties, growing flood and pest / disease resistant varieties, diversification in crop production, multiple cropping, adoption of minimum/zero tillage, adjusting the planting calendar and moderate use of agro-chemicals and fertilizers among others. The need for active collaboration among the rice farmers and other stakeholders to create more awareness and scale-up the identified adaptation measures and the development of new ones was recommended.
\end{abstract}

\section{Introduction}

Climate change leads to an increase in the frequency, intensity and duration of floods and droughts and also heat waves (Kuta, 2011). Building Nigeria's Response to Climate Change (BNRCC), (2008) notes that climate change or global warming has become a new reality, with deleterious effects: seasonal cycles are disrupted, as are ecosystems; agriculture, water needs and supply, and food production are all adversely affected. Climate change also leads to sea-level rise with its attendant consequences, and includes fierce weather, increased frequency and intensity of storms, floods, hurricanes, droughts, increased frequency of fires, poverty, malnutrition and series of health and socio-economic consequence. 
Minimizing the impacts of climate change requires adaptation. Adaptation to climate change is action that minimizes the consequences of actual and expected changes in the climate (Parliamentary Office of Science and Technology (POST, 2006). It refers to adjustment in natural or human systems in response to actual or expected climatic stimuli or their effects, which moderates harm or exploits beneficial opportunities (IPCC, 2007). However, the end goal of all adaptation is to address climate risks, enhance resilience and reduce vulnerability. Effective adaptation initiatives for peasant farmers according to Gumm (2010) must be put in place. Therefore, poverty eradication programmes must be pursued with vigour at all levels of government aimed at empowering people particularly the peasant farmers, to increase their ability to cope with the challenges of climate change. There is also the need to build the adaptive capacity of our local farmers and fishermen who depend on agriculture as the only source of food and source of income. There must be an effective sensitization programme to bring this awareness to the people. Schools are expected to establish climate change clubs, development of manuals for training and enlightenment on climate change using local languages to ensure grassroots mobilization. In order to ensure effective adaptation measures, Kuta (2011) suggested that there must be strategic investment, research and development together with local, national and international cooperation to improve agriculture, water management and water storage and saving. Battling desertification requires a well-coordinated, wellplanned and well-funded approach.

Rice is a major cereal in Nigeria in terms of its output and land area. Rice is currently grown in more than $70 \%$ of the states in the country. In spite of availability of cultivable land area, the current level of demand for rice in Nigeria is about 5 million metric tonnes which is more than twice the quantity produced (2.2 metric tonnes). About 4.9 millions hectares are suitable for rice production but just about $1.8(37 \%)$ are currently utilized for cultivation (Ajetomobi, Abiodun and Hassan, 2010). To tackle the problem, they recalled that West African Rice Development Association (WARDA), International Institute for Tropical Agriculture (IITA) and Ministry of Agriculture are frequently improving adaptation measures in rice production than other cereals. In 2009 for instance, the nation spent more than 66.67 million US dollars in public private partnership schemes to improve the irrigation systems and set up about 17 new rice processing mills.

Rice production is one of the major primary sources of cash income for farmers in Anambra state. Rice is produced under upland, swamp and irrigated lowlands and is dominated by small holder farmers who cultivate small hectares of land between one to two hectares (Nwalieji, 1999). National Cereals Research Institute, NCRI (2004) identified constraints that limit rice production efforts by farmers to include problems with: research; pests and disease management; soil fertility; simple and cheap farm implements; institutional and infrastructural support; credit facilities; improved input delivery; marketing channels; irrigation facilities and extension services. Ramirez (2010) noted that the challenges for rice production are twofold: coping with population growth while also facing climate change. Unforeseen changes associated with global warming in temperature, carbon dioxide and rainfall according to him are expected to impact rice production. The major 
problems associated with rice production according to Ajatomobi, Abiodun and Hassan (2010) included drought, flooding, salt stress and extreme temperatures, all of which are expected to worsen with climate change. Drastic changes in rainfall patterns and rise in temperatures will introduce unfavourable growing conditions into the cropping calendars thereby modifying growing seasons which could subsequently reduce productivity.

From the foregoing observations, it is pertinent to note that there are some evidences of vulnerability of rice production to climate change in the study area. And so, there is need for the study to examine the farm level adaptation that rice farmers make to minimize the effect or impact of climate change in the study area.

\section{Purpose of study}

The major purpose of the study was to examine adaptation practices to climate change among rice farmers in Anambra State, Nigeria. Specifically, the objectives were to:

1. determine rice farmers' level of awareness of climate change; and

2. identify adaptation measures to the impact of climate change on rice production.

\section{Methodology}

The study took place in Anambra State of Nigeria. The state comprises 21 Local Government Areas (LGAs) and four agricultural zones (AZs) - Aguata, Anambra, Awka and Onitsha. There are 6 blocks in Aguata AZ, 4 blocks in Anambra AZ, 5 blocks in Awka AZ and 6 blocks in Onitsha AZ. The climate is typically equatorial with two main seasons, the dry and the rainy seasons. The state experiences dry season from late October to early May and has at least six dry months in the year. The soil types of the area are suitable for varieties of crop production. The vegetation is rainforest and wooden savannah and grasslands in the weather fringes. The state is drained by five rivers and their tributaries.

The population of the study consisted of all the rice farmers in the four AZs of Anambra State. Multistage sampling technique was applied in the selection of respondents for the study. The first stage involved purposive selection of Anambra zone out of the $4 \mathrm{AZs}$ in the state because of the high activities of rice production in the area. Second stage involved purposive selection of two blocks (Anambra East and Ayamelum) out of the 4 blocks due to the same reason. Third stage was also the purposive selection of three most rice producing circles/communities (Omor, umumbo, and Ifite-Ogwari) from Ayamelum block and two circles (EnuguOtu and Eziagulu-Otu) from Anambra East block, giving a total number of five circles/ communities selected. Stage four involved selection of twenty rice farmers from each circle/community using simple random sampling technique. This gives a total sample of hundred (100) respondents. An interview schedule was used to 
collect data for the study. The interview schedule consists of structured questions. It was divided into sections to elicit information based on the objectives.

Objective 1: The respondents were asked first to indicate their level of awareness on a 4-point Likert type scale and their response categories were: Highly Aware, Aware, Moderately Aware, and Not Aware. Secondly, their source(s) of information on awareness of climate change was measured as personal observation/ experience, radio/ TV, extension agents, fellow farmers, etc. Thirdly, they were asked to indicate whether they have observed any significant changes in any of the weather elements and their responses were: Yes or No. Objective 2: A list of local possible adaptive measures obtained from literature and field observation were made available and the respondents indicated the options they adopted on a 3-point likert type scale as follows: very effective $=2$, effective $=1$ and not effective $=0$. Any item with a mean greater than or equal to 1 was regarded as an effective adaptive measure. Objective 1 was achieved using percentage and mean scores, while objective 2 was analyzed using mean statistic.

\section{Results and Discussion}

\section{Farmers' level of awareness of climate change}

Table 1 shows that majority $(80.0 \%)$ of the respondents were aware of climate change while the remaining $(20.0 \%)$ were not. This implies that most rice farmers in the area already knew about the concept of climate change. This confirms the assertion of the Southern African Catholic Bishops' Conference (SACBC) (2010) that most Africans are aware that weather and climate patterns are changing but their understanding of global change is limited. On the level of awareness of climate change, the entries indicate that majority $(42.0 \%)$ of the respondents were moderately aware of climate issues while $8.0 \%, 30.0 \%$ and $20.0 \%$ were highly aware, aware and not aware of the change respectively. This shows that many farmers in the area had observed to an extent that there are significant changes in climate pattern. This is in agreement with Ekong (2003) who asserted that local people take cognizant of changes in their immediate environment.

\section{Sources of information on climate change}

Table 1 also shows that greater proportion $(62.0 \%)$ of the respondents were aware of climate change through personal observation and experience while $5.0 \%, 5.0 \%$, $26.0 \%$ and $2.0 \%$ became aware through radio/TV, extension agents, fellow farmers and newspapers respectively. This shows that different sources of information on climate change exist in rural areas but farmers relied more on personal observation and experience. 


\section{Observable description of climate change among respondents}

Table 1 further shows under multiple responses that majority $(88.0 \%)$ of the respondents described climate change as variation in rainfall duration, pattern and intensity. This was followed in decreasing order of description as too much sun and too much rain $(76.0 \%)$, alteration in cropping calendar due to weather $(64.0 \%)$, variation in flood pattern, duration and intensity (64.0\%), prolonged dry and rainy seasons $(56.0 \%)$, thunderstorm and heavy rains $(44.0 \%)$, variation in harmattan pattern and intensity (36.0\%) and variation in day light and day night length $(18.0 \%)$. This implies that observable changes in weather and season constitute most of the farmers' knowledge on climate change as they live with these effects in their day-to-day lives.

\section{TABLE 1}

\section{Distribution of respondents according to awareness on climate change}

\begin{tabular}{ll}
\hline Climate change awareness & Percentage (\%) \\
\hline Awareness & \\
Yes & 80.0 \\
No & 20.0 \\
Level of awareness & \\
Highly aware & 8.0 \\
Aware & 30.0 \\
Moderately aware & 42.0 \\
Not aware & 20.0 \\
Sources of information on climate change & \\
Personal observation/experience & 62.0 \\
Radio/TV & 5.0 \\
Extension agents & 5.0 \\
Fellow farmers & 26.0 \\
Newspapers & 2.0 \\
*Observable descriptions of climate change & \\
Variation in rainfall duration, pattern and intensity & $88.0 \quad 1 \mathrm{st}$ \\
Too much sun and too much rain & $76.0 \quad 2 \mathrm{nd}$ \\
Alteration in cropping calendar due to weather & $64.0 \quad 3 \mathrm{rd}$ \\
Variation in flood pattern, duration and intensity & $64.03 \mathrm{rd}$ \\
Prolonged dry and rainy seasons & $56.0 \quad 4$ th \\
Thunderstorm and heavy rains & $44.0 \quad 5$ th \\
Variation in harmattan pattern and intensity & $36.0 \quad 6$ th \\
Variation in day light and day night length & $18.0 \quad 7^{\text {th }}$ \\
\hline Field Suvey, 2011
\end{tabular}

Field Survey, $2011 \quad$ * = multiple response 


\section{Adaptation measures to climate change in rice production}

Table 2 shows that the effective adaptation measures to the effect/impact of climate change in rice production among the respondents included; use of improved varieties $(M=1.80)$, growing flood resistant varieties $(M=1.35)$, use of pest / disease resistant varieties $(M=1.15)$, diversification in crop production $(M=1.52)$, multiple cropping $(M=1.44)$, adoption of minimum/zero tillage $(M=1.50)$, adoption of recommended improved rice production practices $(M=1.45)$, adjusting the planting calendar $(M=1.05)$, moderate use of agro-chemicals and fertilizers $(M=1.66)$ and improvement on farmers' management skills such as burning of rice farm residues $(M=1.35)$. Other measures with low mean scores were considered not effective. These included growing drought resistant crop varieties, use of weather forecast technologies, prayers for God's special intervention, construction of drainage system, use of suitable irrigation system, out- migration from climate risk zones and recycling of waste products with mean (M) scores of $0.20,0.23$, $0.70,0.60,0.55,0.76$ and 0.20 respectively.

TABLE 2

\section{Mean distribution of respondents according to adaptation measures to climate change in rice production}

\begin{tabular}{lll}
\hline Adaptation measures & Mean (M) & SD \\
\hline Use of improved varieties & $1.80^{*}$ & 0.70 \\
Growing drought resistant crop varieties & 0.20 & 0.30 \\
Growing flood resistant varieties & $1.35^{*}$ & 0.58 \\
Use of pest / disease resistant varieties & $1.15^{*}$ & 0.53 \\
Diversification in crop production & $1.52^{*}$ & 0.61 \\
Use of weather forecast technologies & 0.23 & 0.31 \\
Prayers for God's special intervention & 0.70 & 0.46 \\
Multiple cropping & $1.44^{*}$ & 0.59 \\
Adoption of minimum/zero tillage & $1.50^{*}$ & 0.60 \\
Construction of drainage system & 0.60 & 0.40 \\
Use of suitable irrigation system & 0.55 & 0.39 \\
Out- migration from climate risk zones & 0.76 & 0.48 \\
Adoption of recommended improved rice production practices & $1.45^{*}$ & 0.59 \\
Adjusting the planting calendar & $1.05^{*}$ & 0.52 \\
Moderate use of agro-chemicals and fertilizers & $1.66^{*}$ & 0.66 \\
Recycling of waste products & 0.20 & 0.30 \\
Improvement on farmers' management skills & $1.35^{*}$ & 0.58 \\
\hline *=Effective $(M \geq 1)$ & &
\end{tabular}




\section{Conclusion and Recommendations}

Greater proportions $(62.0 \%)$ of the respondents were aware of climate change through personal observation and experience while majority (88.0\%) described climate change as variation in rainfall duration, pattern and intensity. Adaptation measures to climate change included the use of improved varieties, growing flood and pest / disease resistant varieties, diversification in crop production, multiple cropping, adoption of minimum/zero tillage, adjusting the planting calendar, moderate use of agro-chemicals and fertilizers. Based on the findings above, the following recommendations were made: 1) Farmers level of awareness of climate change should be increased. This could be achieved by the active involvement and participation of relevant stakeholders such as the government, research institutions, non-governmental organizations (NGOs), community based organizations (CBOs) and associations, in teaching farmers those activities that help alleviate climate change. 2) A special climate change office/ committee with trained staff should be created under extension service to provide information and support to farmers at all levels. 3) There is need for active collaboration among the rice farmers and other stakeholders to create more awareness and scale-up the identified adaptation measures and the development of new ones.

\section{References}

Ajetomobi, J., Abiodun, A., and Hassan, R. (2010). Economic impacts of climate change on rice agriculture in Nigeria. Tropical and Subtropical Agroecosystems, 14(2011): 613-622. Building Nigeria's Response to Climate Change (BNRCC). (2008). Climate change. Retrieved on $20^{\text {th }}$ September, 2011 from http://www.nigeriaclimatechange.org/...mht.

Ekong, E. E. (2003). Introduction to rural sociology. Dove Educational Publishers: Uyo, Nigeria: 33.

Gumm, Daniel (2010). Nigeria: Climate change to affect rice yields. Vanguard, August19. Retrieved on September 20 ${ }^{\text {th }}, 2011$ from http://allafrica.com/nigeria/climate...

International Panel on Climate Change, (IPCC). (2007). Climate change 2007: Impacts, adaptation and vulnerability: Contribution of Working Group II to the Fourth Assessment report of the IPCC. Cambridge UK: Cambridge University Press.

Kuta, D. A. (2011). Nigeria: Climate change and agriculture in country. Leadership (Abuja), September 18. Retrieved on September 20 ${ }^{\text {th }}, 2011$ from http://allafrica.com/nigeria/climate...

National Cereal Research Institute (NCRI) (2004). Training manual on rice production produced for the Presidential Initiative on Paddy Production for Abakiliki and Omor Rice mills and other rice processors in south east zone of Nigeria held at Umudike, Abia State. Pp.1-128 
Nwalieji, H. U. (1999). The impact of lower Anambra irrigation project (LAIP) on improved rice production in Ayamelum LGA of Anambra state, Nigeria. B. Agric. project, Dept. of Agricultural Extension, University of Nigeria, Nsukka.

Parliamentary Office of Science and Technology (POST), (2006). Adapting to climate change in developing countries. Postnote October, Number 269, Page 2. Retrieved on November $20^{\text {th }}, 2011$ from www.parliament.uk/post

Ramirez, A. (2010). The impact of climate change on rice production. http://allafrica.com/nigeria/climate.

Southern African Catholic Bishops' Conference, (SACBC). (2010). South African's awareness of climate change. Brief Paper 235. Parliamentary Liason Office. http://www.cplo.org.za. Retrieved on September $6^{\text {th }}, 2011$. 